\title{
KRIOPRESERVASI SPERMATOFOR DAN INSEMINASI BUATAN PADA UDANG GALAH, TAHAP AWAL TRANSGENESIS UDANG GALAH
}

\author{
Ikhsan Khasani \\ Balai Penelitian Pemuliaan Ikan \\ Jl. Raya Sukamandi No. 2, Subang 41256 \\ E-mail: ikhsankhasani@ yahoo.com
}

\begin{abstract}
ABSTRAK
Teknologi transfer gen, yang lebih dikenal sebagai transgenesis, diharapkan dapat menjadi salah satu solusi guna mempercepat penyediaan induk ikan dan udang unggul di Indonesia. Pada banyak spesies ikan, keberhasilan teknologi transgenesis telah mampu membentuk strain ikan dengan performa tumbuh hingga $200 \%$ dari ikan normal. Agar teknologi transfer gen dapat dilakukan, maka teknik fertilisasi dan penetasan buatan harus dikuasai dengan baik. Spesifik pada udang galah, produksi larva hampir selalu dilakukan dengan sistem pemijahan dan penetasan telur alami, karena dirasa lebih mudah dan menguntungkan sehingga teknologi inseminasi dan penetasan buatan kurang berkembang. Namun demikian, mengingat persyaratan tahap transgenik tersebut maka teknologi inseminasi dan penetasan telur buatan pada udang galah harus segera dikuasai sehingga program transfer gen dapat dilakukan di Indonesia. Informasi keberhasilan pengambilan sperma, preservasi sperma, transfer gen, pembuahan buatan, dan penetasan buatan pada udang galah merupakan hal menarik yang akan penulis uraikan dalam artikel ini. Tujuan utama transfer gen pada udang galah adalah mendapatkan strain udang galah tumbuh cepat dan tahan penyakit sehingga mampu mendukung peningkatan produksi udang galah nasional.
\end{abstract}

KATAKUNCl: inseminasi buatan, sperma, transgenesis, udang galah

\section{PENDAHULUAN}

Kebutuhan benih udang galah unggul dirasa semakin mendesak, seiring pesatnya budidaya udang galah di Indonesia dan tuntutan pengembangan sistem budidaya yang kompetitif. Benih dengan potensi tumbuh yang cepat diharapkan dapat menekan biaya produksi dan meningkatkan kapasitas produksi tahunan kolam budidaya, tentunya dengan durasi pemeliharaan yang lebih cepat. Mekanisme produksi benih unggul telah ditempuh melalui pendekatan breeding program, baik seleksi maupun hibridisasi, meskipun hasilnya belum signifikan memberikan sumbangsih bagi peningkatan produksi udang galah nasional. Teknologi terkini, yang diharapkan dapat mempercepat pembentukan strain udang galah dengan potensi tumbuh cepat adalah transgenesis, karena telah terbukti mampu meningkatkan potensi tumbuh berbagai jenis ikan hingga 200\% (Sarmasik, 2003).

Perkembangan metode transgenesis telah memungkinkan transfer gen (TG) dilakukan dengan berbagai cara, yaitu mikroinjeksi, elektroforesis, TG menggunakan bantuan vektor, dan TG menggunakan bantuan sel (Alimuddin et al., 2003). Transgenesis pada ikan dilakukan melalui berbagai metode, yang sudah cukup lama berkembang melalui transfer DNA asing, baik ke inti sel telur, sitoplasma embrio yang berkembang, dan telur yang sudah terbuahi. Elektroforesis fragmen DNA asing ke telur yang sudah terbuahi adalah teknik yang lebih populer bila dibandingkan teknik mikroinjeksi konvensional, dengan beberapa kelebihan, yaitu lebih sederhana, tingkat keberhasilan tinggi, dan efisien (Sarmasik, 2003). Namun demikian, kehandalan transfer gen melalui elektroforasi pada telur yang sudah terbuahi masih belum cukup menjanjikan untuk telur dalam jumlah banyak (Shi-Shen Li \& Huai-Jen Tsai, 2000).

\section{Transgenesis pada Ikan}

Selama ratusan tahun manusia berusaha meningkatkan kualitas induk ikan melalui program seleksi. Beberapa program seleksi telah menunjukkan keberhasilan peningkatan performa tumbuh ikan dengan rata-rata perbaikan genetik (genetic gain) sebesar 10\%20\% per generasi (Gjedrem \& Baranski, 2009). Namun demikian, seiring kebutuhan industrialisasi akuakultur yang menuntut efisiensi biaya dan waktu maka pengembangan bioteknologi yang memungkinkan percepatan sistem produksi melalui penggunaan benih dengan performa tumbuh "super cepat" terus digalakkan. 
Dalam dua dekade, transgenesis telah dilakukan pada lebih dari 35 spesies ikan. Sebagian besar transgenesis tersebut diarahkan untuk meningkatkan karakter pertumbuhan (Beaumont \& Hoare, 2003), melalui transfer konstruksi gen GH (growth hormon), karena pertumbuhan merupakan parameter terpenting dalam produksi ikan. Karakter lain yang menjadi sasaran program transgenesis pada ikan adalah ketahanan terhadap penyakit, ketahanan terhadap suhu rendah, dan toleran terhadap salinitas (Nam et al., 2001). Dalam perkembangannya, berbagai metode transfer gen telah berhasil diciptakan, seperti mikroinjeksi dan elektroforasi. Keberhasilan transgenesis sangat ditentukan oleh karakter objek yang akan ditransfer gen asing tersebut, yaitu sel sperma, sel telur, atau telur yang telah terbuahi (embrio telah berkembang). Pemilihan metode yang tepat berdasarkan karakter-karakter biologis tersebut akan menjamin efektivitas keberhasilan transfer gen.

Elektroforesis fragmen DNA asing ke telur yang sudah terbuahi adalah teknik yang populer bila dibandingkan teknik mikroinjeksi konvensional, dengan beberapa kelebihan, yaitu lebih sederhana, tingkat keberhasilan tinggi, dan efisien. Namun demikian, kehandalan transfer gen melalui elektroforasi pada telur yang sudah terbuahi masih belum cukup tinggi untuk telur dalam jumlah banyak dan dalam waktu pendek (Shi-Shen Li \& Huai-Jen Tsai, 2000).

Terkhusus pada hewan air, ketertarikan sistem transfer gen melalui media sperma semakin meningkat dikarenakan beberapa keuntungan yang diberikan. Pertama, transfer gen melalui sperma (TGMS) dapat diaplikasikan untuk telur dalam jumlah sangat besar. Kedua, TGMS lebih efektif dibandingkan transfer gen konvensional karena pada transfer gen konvensional sering dihadapkan pada kendala karakter telur yang buram, tebal, mengapung, dan memiliki pelapis (chorion) yang tebal. Ketiga, DNA asing yang dibawa melalui sperma akan ditransfer masuk ke nukleus (inti sel) sehingga peluang berhasilnya lebih tinggi. Pada sistem elektroforasi masih ada kendala bila volume blastodisc sangat kecil, misalnya pada telur yang sudah terbuahi, sehingga peluang fragmen DNA tertransfer masuk ke-blastodisc sangat kecil. Keempat, sperma ikan dan udang dapat diaktivasi dengan menambahkan air sehingga dapat diawetkan (cryopreservasi). Jadi sperma selalu siap digunakan setiap waktu (SI-Shen Li \& Huai-Jen-Tsai, 2000).

Berdasarkan serangkaian pengujian transgenesis pada kelompok krustase, hanya ada sedikit metode yang terbukti efektif. Gendreau \& Clleagus (1995) dalam
SI-Shen Li \& Huai-Jen-Tsai, 2000 melaporkan bahwa teknik ballistik walau dapat digunakan untuk mentransfer gen asing ke Artemia sp. namun membutuhkan investasi yang sangat besar dengan capaian yang kurang memadai untuk skala massal. Bensheg \& khoo (1997) dalam SI-Shen Li \& Huai-Jen-Tsai, 2000 juga telah berhasil mentransfer gen tertentu dalam udang tawar, Macrobrachium lanchesteri, namun demikian teknik mikroinjeksi tersebut bersifat laboratoris, memerlukan waktu lama, dan hanya kurang efektif untuk telur dalam jumlah banyak. Selanjutnya, SI-Shen Li \& Huai-Jen-Tsai (2000) menjelaskan ada teknik yang efektif dan akurat diterapkan untuk transfer gen pada udang galah. Terkait metode trangenesis tersebut, maka serangkaian teknik pendukung harus dikuasai dengan baik sehingga produksi udang galah super growth dapat terwujud. Teknik-teknik terkait tersebut adalah teknik pengambilan sperma (artificial ejaculation), pemijahan buatan (artificial insemination), dan pengaw etan sperma (sperm cryopreservation).

\section{Teknik Pengambilan Sperma}

Beberapa penelitian untuk meningkatkan keragaan reproduksi udang galah telah dilakukan dan menunjukkan kemajuan, di antaranya melalui manipulasi lingkungan, yang dapat diaplikasikan pada sistem pemijahan udang galah yaitu teknik pemijahan buatan (artificial insemination). Pemijahan buatan, melibatkan intervensi manusia dalam proses pemijahan, berguna untuk melindungi biota dari pemangsa dan kondisi yang tidak menguntungkan seperti perubahan suhu secara fluktuatif, mengupayakan kondisi yang lebih baik untuk udang dapat tumbuh dan bertahan hidup, serta menghasilkan tingkat pembuahan dan penetasan yang lebih baik. Teknik pemijahan buatan dapat meningkatkan produktivitas pembenihan karena dapat memproduksi larva di luar musim pemijahannya. Pemijahan buatan juga dapat diterapkan untuk program kawin silang (Soundarapandian \& Kannupandi, 2000), yang pada beberapa kasus udang dari alam belum dapat dipijahkan secara alami di kolam budidaya (Khasani, 2009, tidak dipublikasikan).

Salah satu faktor yang mempengaruhi keberhasilan pemijahan adalah kualitas sperma. Toelihere (1981) menyatakan bahwa kualitas sperma merupakan faktor penting yang dapat menentukan pemijahan, yaitu kemampuan dalam membuahi sel telur. Pengambilan sperma pada induk jantan dapat dilakukan dengan cara manual, yaitu menekan spermatofor secara hati-hati sampai spermatofor keluar dari lubang genital (Gwo, 2000). Selain itu, spermatofor juga dapat dikeluarkan dengan menggunakan kejutan listrik (Jerry, 2001). 
Kejutan listrik terjadi jika medan listrik mengenai sel hidup. Paparan medan listrik ini merupakan faktor eksternal dari lingkungan berupa rangsangan melalui induksi kejutan listrik. Menurut Nair (1989), induksi pada benda hidup disebabkan adanya muatan-muatan listrik bebas yang terdapat pada ion kaya cairan seperti darah, getah bening, otot, dan syaraf yang dapat terpengaruh gaya yang dihasilkan oleh aliran arus listrik. Oleh karena itu, diharapkan rangsangan lingkungan berupa induksi kejutan listrik yang diterima oleh ganglion otak dapat membantu kerja Organ $Y$ yaitu organ penghasil hormon perangsang gonad (Gonad Stimulating Hormone, GSH) dalam pembentukkan sperma pada induk jantan udang galah. Keberhasilan induksi kejutan listrik ini mengandalkan kisaran voltase yang digunakan mengingat besar dan kecilnya aliran arus listrik dapat mempengaruhi ion kaya cairan seperti darah, getah bening, otot, dan syaraf.

Teknik pengambilan sperma melalui kejutan listrik telah berhasil dilakukan di Balai Penelitian Pemuliaan Ikan, Sukamandi, dengan voltase optimal sebesar $9 \mathrm{~V}$, yang memberikan data keberhasilan pengambilan spermatofor $100 \%$ viabilitas sperma norma, abnormal itas sperma $0 \%$ dan kematian induk 0\%(Mutiasari, 2010). Pengambilan spermatofor melalui kejutan dilakukan dengan menempelkan salah elektro da (menggunakan electrostimulation $25 \mathrm{mV}$ ) dipangkal kaki jalan kelima, dan satu elektroda lainnya disentuhkan selama 1 detik pada pangkal kaki jalan kelima lainnya. Kejutan dilakukan dalam 3-5 ulangan. Posisi bagian yang diberi perlakuan kejutan ditampilkan pada Gambar 1.

Kejutan listrik dapat mempengaruhi sistem koordinasi yang terdapat dalam tubuh udang. Sistem koordinasi pada hewan meliputi sistem saraf beserta indera dan sistem endokrin (hormon). Pada udang adanya rangsangan dari luar akan diterima oleh sistem syaraf pusat (SSP) dan selanjutnya diteruskan ke organ Y, kemudian organ Y akan menyekresikan gonado somatic hormone (GSH) yang berfunsi untuk merangsang hormon androgen dalam mengatur pengeluaran sperma (Gambar 2).

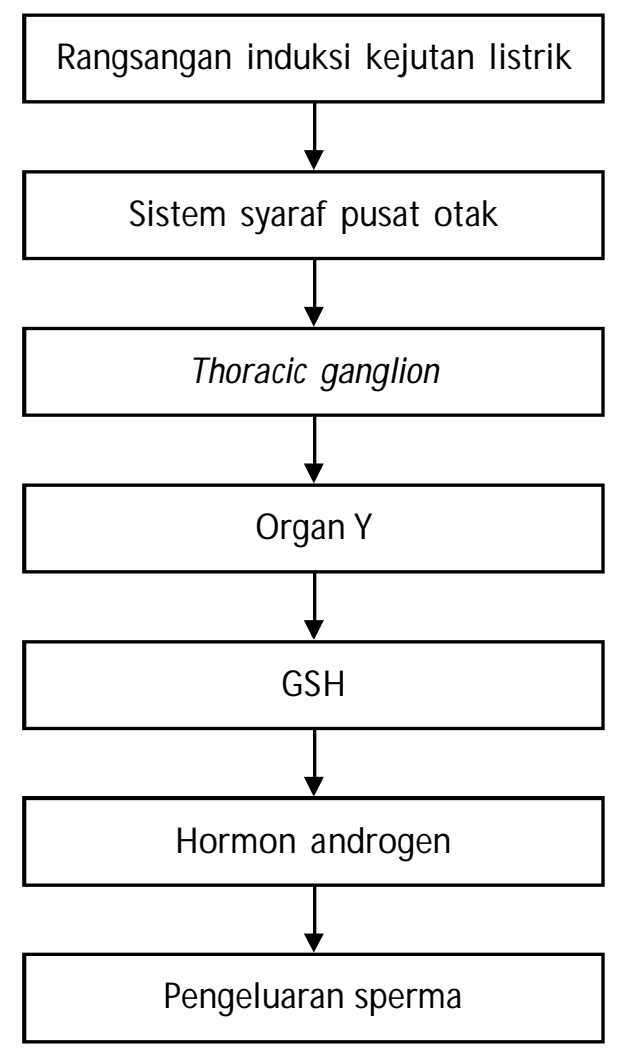

Gambar 2. Proses rangsangan induksi kejutan listrik

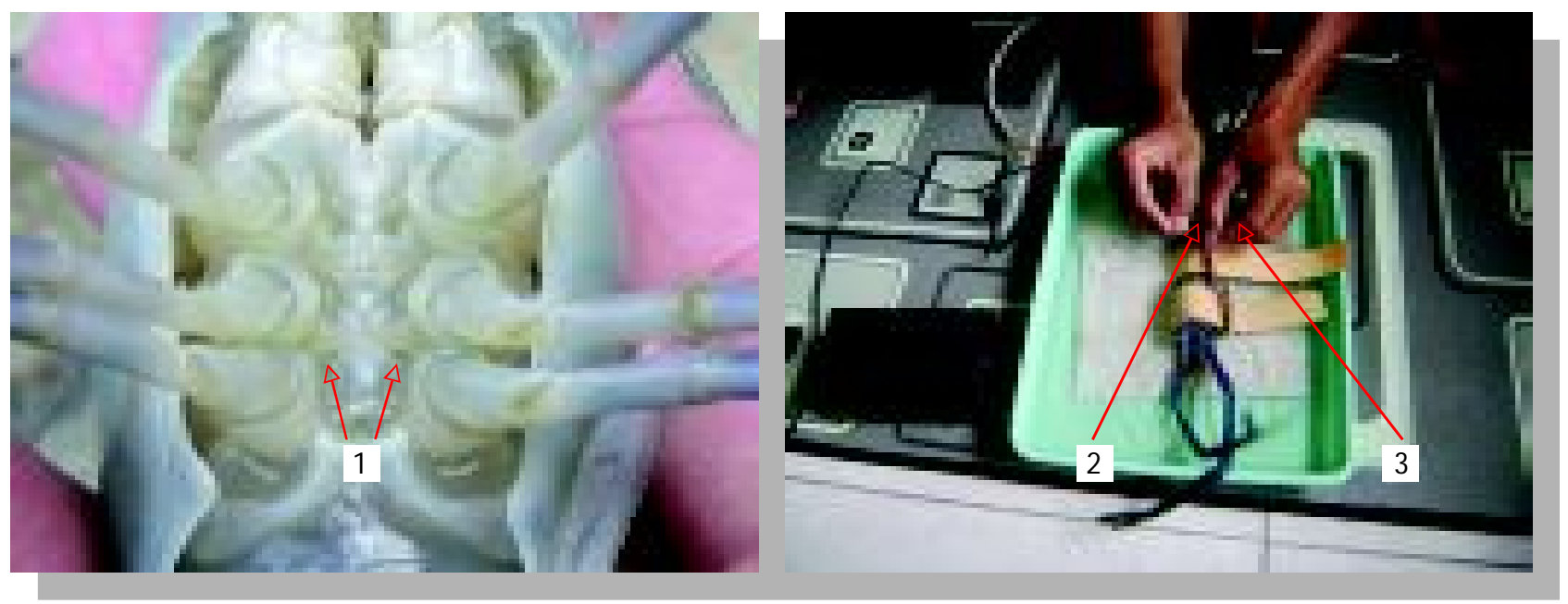

Gambar 1. Posisi kelamin udang galah jantan (kiri) dan perlakuan kejutan listrik (kanan), (1. Petasma, 2. Elektroda negatif, 3. Elektroda positif) 


\section{Inseminasi Buatan}

Udang galah termasuk hewan yang heteroseksual yaitu mempunyai jenis kelamin jantan dan betina yang terpisah. Organ reproduksi utama dari udang jantan adalah testes, vasa der efensia, apendiks maskulina, dan petasma. Petasma merupakan modifikasi bagian endopodit pasangan kaki renang pertama. Sistem reproduksi udang galah betina terdiri atas sepasang ovarium, sepasang oviduk, lubang genital, dan thelycum. Thelycum terletak di bagian ventral dada pada pasangan kaki jalan ketiga terdiri atas lempeng kecil anterior dan sepasang plat (lempeng) yang agak besar. Thelicum berongga tetapi tertutup rapat oleh ketiga lempeng tersebut. Rongga ini berfungsi sebagai tempat menyimpan sperma yang ditempelkan udang jantan bila terjadi perkawinan. Lempeng-lempeng penutup thelicum cukup keras tetapi transparan sehingga ada tidaknya sperma di dalam dapat terlihat bila diterawang.

Pada sistem pemijahan normal, udang galah dewasa berumur minimal 6 bulan dipelihara secara komunal di kolam dengan mencampurkan 2-3 jantan untuk 10 ekor betina (D'Abramo et al., 1995). Secara umum, di daerah tropis udang galah dapat memijah sepanjang tahun secara alami. Pengamatan bulanan terhadap populasi udang galah dewasa yang dipelihara secara bersamaan antara jantan dan betina akan diperoleh udang yang bertelur (sudah berhasil dibuahi) sekitar 25\%30\% Jadi, ketersediaan larva bukan merupakan kendala utama sistem produksi benih udang galah bila tersedia induk udang dalam jumlah memadai. Sebagai gambaran, induk udang galah dengan ukuran 30-40 g dapat menghasilkan larva sekitar 20-25 ribu ekor.

Pada kondisi lingkungan optimal, khususnya terkait suhu air dan ketersediaan nutrisi, maka udang galah jantan mampu membuahi betina hingga 5 ekor dalam waktu hampir bersamaan, sehingga sistem pemijahan dengan rasio kelamin 1 jantan : 5 betina masih efektif untuk produksi larva (Ali, 2006). Dijelaskan oleh D'Abramo et al. (1995) bahwa pada sistem produksi larva secara alami, proporsi induk jantan capit biru, capit oranye, dan udang galah ukuran kecil yang dipijahkan harus tepat, yaitu untuk setiap jantan capit biru (BlueClaw, BC) harus ditempatkan 3-4 jantan capit oranye (Orange Claw, OC). Hal tersebut karena adanya potensi reproduksi yang berbeda antar jenis pejantan. Fenomena lain yang perlu diketahui adalah bahwa pada umur tertentu kapasitas reproduksi jantan BC sangat berkurang, dan baru akan aktif kembali setelah ganti kulit.

Di samping sistem pemijahan alami sebagaimana diuraikan di atas, telah dirintis teknik pemijahan (inseminasi) buatan yang diharapkan akan berguna dalam mendukung program pemuliaan udang galah, khususnya transfer gen. Dikarenakan kualitas sperma sangat berpengaruh terhadap derajat fertilitas telur, maka pemilihan induk jantan dan teknik pengambilan sperma yang tepat harus dijalankan secara seksama.

Teknik pemijahan buatan melibatkan kegiatan reproduksi induk udang jantan yang meliputi proses penyatuan spermatofor udang jantan ke dalam tellicum udang betina sehingga terjadi proses pembuahan. Spermatofor memegang peranan penting dalam pemindahan dan penyimpanan spermatozoa pada udang (Lante \& Haryanti, 2005), sehingga kualitasnya harus dijaga. Salah satu ciri spermatofor yang baik adalah tidak terdapat melanisasi pada permukaannya. Proses penyatuan sperma di thelicum ditampilkan pada Gambar 3.

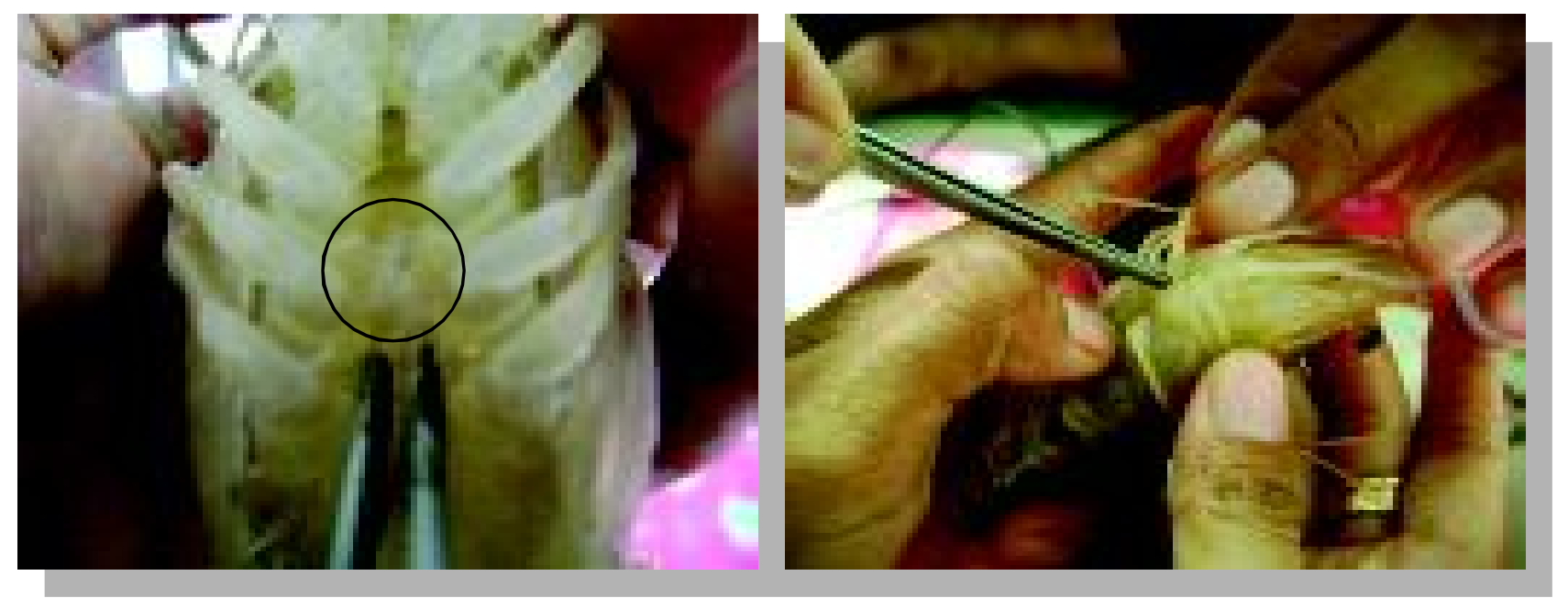

Gambar 3. Posisi lubang genitalia betina, thelicum (kiri) dan proses penempelan spermatofor pada thelicum (kanan) 
Selain ditentukan oleh kualitas induk jantan dan sperma yang disiapkan, pemijahan buatan akan berhasil bila dilakukan terhadap induk betina yang telah siap memijah. Udang galah yang matang kelamin ditandai dengan adanya warna kuning pada ovarium yang teramati jelas di bagian dorsal cephalothorax, disebut tingkat kematangan gonad (TKG) III, selanjutnya ovarium berkembang menjadi oranye, dan pada TKG V menjadi kemerahan. Pada saat tersebut udang berganti kulit (premating moult) dan tidak lama berselang siap dibuahi (New \& Valenti, 2000). Jadi, guna mendapatkan induk betina untuk pemijahan buatan diperlukan persiapan dan pengamatan sejumlah induk betina, sehingga didapat induk betina yang baru premating moult.

Teknik pemijahan buatan pada golongan krustase telah dilakukan, di antaranya pada udang windu, vanamei, dan lobster. Akan tetapi, teknik pemijahan buatan pada udang galah belum banyak dilakukan, terutama di Indonesia. Inseminasi buatan pada udang galah telah dilakukan oleh Bart et al. (2006) yang melaporkan bahwa pemijahan buatan pada udang galah menggunakan spermatofor hasil pembekuan memberikan hasil derajat pembuahan cukup tinggi, hingga 79,9\%dari jumlah induk betina perlakuan. Proses embriogenesis telur dari hasil inseminasi buatan juga tergolong tinggi sehingga daya tetas telur mencapai $87,8 \%$

\section{Penyimpanan Sperma (Sperm Cryopreservation)}

Kriopreservasi atau penyimpanan gamet sangat berperan dalam inseminasi buatan, program seleksi, konservasi gen, dan penyediaan gamet sesuai waktu (Akarasanon et al., 2004). Kriopreservasi gamet pada organisme akuatik telah dikuasai dengan baik dan dilakukan pada lebih dari 200 spesies ikan tawar dan laut (Bart et al., 2006).

Selama ini, kriopreservasi sperma pada udang kurang mendapat perhatian karena pada industri penyediaan benih udang windu dan udang galah produksi larva dilakukan dengan pemijahan alami. Namun demikian, terkait beberapa program pemuliaan dan konservasi gen maka inseminasi buatan harus dilakukan, sehingga ketersediaan sperma berkualitas baik juga harus diperhatikan. Beberapa teknik penyimpanan sperma telah dikuasai, baik untuk tujuan penyimpanan jangka pendek maupun penyimpanan jangka panjang. Dilaporkan oleh Chow (1982) dalam Akarasanon et al. (2004), bahwa sperma udang galah dapat disimpan selama 96 jam dalam suhu $2^{\circ} \mathrm{C}$, dan dapat bertahan hingga 31 hari bila disimpan dalam larutan nitrogen.
Persiapan sperma dilakukan dengan diawali pengambilan spermatofor melalui kejutan listrik. Selanjutnya spermatofor yang diperoleh disimpan dalam micro tube volume $2 \mathrm{~mL}$ yang telah diisi bahan krioprotektan berupa gliserol (G) atau etilen gliserol (EG). Guna keperluan jangka pendek, spermatofor dalam krioprotentan tersebut cukup disimpan dalam suhu $-20^{\circ} \mathrm{C}$, dan ternyata mampu mempertahankan kualitas sperma hingga 10 hari penyimpanan. Sementara itu, apabila sperma akan disimpan dalam jangka waktu lebih lama, hingga 150 hari, maka penyimpanan dilakukan pada suhu $-196^{\circ} \mathrm{C}$. Jadi efisiensi penyimpanan spermatofor udang galah ditentukan oleh jenis bahan krioprotektan dan suhu penyimpanan.

\section{KESIMPULAN}

Upaya pemenuhan kebutuhan protein hewani ditempuh melalui penerapan bioteknologi dalam berbagai aspek, termasuk reproduksi. Keberhasilan transfer gen pada beberapa spesies ikan mendorong manusia untuk mengembangan teknik tersebut pada sejumlah spesies potensial lainnya, termasuk udang galah. Penguasaan teknik penyediaan dan penyimpanan sperma, serta inseminasi buatan pada udang galah merupakan faktor penunjang menuju keberhasilan program transfer gen pada udang galah.

\section{DAFTAR ACUAN}

Akarasanon, K., Damrongphol, P., \& Poolsanguan, W. 2004. Long-term cryopreservation of spermatophore of the giant freshwater prawn, Macrobrachium rosenbergii de Man. Aquaculture Research, 35: 1,4151,420 .

Ali, F. 2006. Tingkat Produktivitas Induk Udang Galah (Macrobrachium rosenbergii) Pada Budidaya Dengan Sistem Resirkulasi. Limnotek, 13(1): 56-63.

Alimuddin, Yoshizaki, G., Carman, 0., \& Sumantadinata, K. 2003. Aplikasi transfer gen dalam akuakultur. J. Akuakultur Indonesia, 2(1): 41-50.

Bart, A.N., Choosuk, S., \& Thakur, D.P. 2006. Spermatophore cryopreservation and artificial insemination of black tiger shrimp, Penaeus monodon (Fabricius). Aquaculture Research, 37: 523-528.

Beaumont, A.R. \& Hoare, K. 2003. Biotechnology and genetics in fisheries and aquaculture. Blackwell Publishing, Oxford, ix + $155 \mathrm{pp}$.

D'Abramo, L.R., Daniels, W.H., Fondren, M.W., \& Brunson, M.W. 1995. Management Practices for culture of freshwater prawn (Macrobrachium rosenbergii) intemperate climates. MAFES Bulletin 1030, 12 pp. 
Gjedrem, T. \& Baranski, M. 2009. Selective breeding in aquaculture: an introduction. Springer Science, London, $217 \mathrm{pp}$.

Gwo, J.-C. 2000. Cryopreservation of sperm of some marine fishes, in: Cryopreservation in Aquatic Species, Tiersch, T.R. \& Mazik, P.M. (Eds.) Advances in World Aquaculture, 7, 138, 2000, Baton Rouge, LA, USA. World Aquaculture Society.

Harris, S.E. \& Sandifer, P.A. 1986. Sperm Production and The Effects of Electrically Induced Spermatophore Expulsion in The Prawn Macrobrachium rosenbergii de Man. J. of Crustaceans Biology, 6(4): 633-647.

Jerry, D.R. 2001. Electrical stimulation of spermatophore extrusion in the freshwater yabby (Cherax destructor). CSIRO Livestock Industries, Locked Bag 1, Armidale, NSW 2350, Australia.

Lante, S. \& Haryanti. 2005. Keragaman sel sperma udang windu Penaeus monodon Fab. Asal laut dan tambak. J. Pen. Perik. Indonesia, 11(7): 13-18.

Mutiasari, T. 2010. Efektivitas kejutan listrik terhadap pengeluaran spermatophor dan kualitas sperma udang galah. Skripsi. Fakultas Perikanan dan IImu Kelautan UNPAD, Bandung.

Nair, I. 1989. Biological Effects of Power Frequency Electric and Magnetic Fields. Background Paper, Assesment of Electric Power Wheeling and Dealing: Technological Consideration for Increasing Competition, OTABP-E-53, Washington DC: U.S. Government Printing Office.

Nam, Y.K., Noh, J.K., Cho, Y.S., Cho, H.J., Cho, K.N., Kim, G., \& Kim, D.S. 2001. Dramatically accelerated growth and extraordinary gigantism of transgenic mud loach M isgurnus mizolepis. Trans Res., 10: 353-362.

New, M.B. \& Valenti, W.C. 2000. Freshwater prawn culture: The farming of Macrobrachium rosenbergii. Blackwell Science, Oxford, xix + 435 pp.

Sarmasik, A. 2003. Application of Gene Transfer Technology for Genetic improvement of Fish. Turk. J. Zool., 27: 1-6.

Soundarapandian, P. \& Kannupandi, T. 2000. Larval production by crossbreeding insemination of freshwater prawns. Indian J. Fish, 47(2): 97-101.

SI-Shen Li \& Huai-Jen Tsai. 2000. Transfer of foreign gene to giant freshwater prawn (M acrobrachium rosenbergii) by spermatophore-microinjection. M olecular Reproduction and Developmen, 56: 149-154.

Toelihere, M.R. 1981. Fisiologi Reproduksi pada Ternak. Angkasa, Bandung, $237 \mathrm{hlm}$. 